\title{
PENYEGARAN PENDIDIKAN ISLAM ; WACANA REDEVINISI DAN DEKONSTRUKSI
}

\author{
Faizal Rois Fatahillah ${ }^{1}$
}

\begin{abstract}
The Development of Islamic Education requires strong and detail epistemology that can only be resulted from complete understanding about classical inheritance about Islamic Education and then combined with detail understanding about issue and challenge that faced by Islamic Education at present and future. In this context, a scholar of Islamic education requires to know classical inheritance about Islamic Education in his major well, and then mapping and searching the relevance to the condition of Islamic Education at the present and future.
\end{abstract}

Keywords: Islamic Education, Redivinisi, Deconstruction.

\section{A. Pendahuluan}

Dalam sistem pendidikan nasional, di Indonesia pendidikan Islam menempati posisi formal yang boleh dikatakan sangat kokoh, sebab setelah menapaki sepanjang perjalanan sejarahnya, sejak negara kepulauan ini menyandang kemerdekaan penuh sebagai negara berdaulat, negara telah menjamin penyelenggaraan pendidikan Islam, mulai dari tingkat pra sekolah, tingkat dasar, menengah sampai tingkat pendidikan tinggi.

Nilai urgensi penyelenggaraan pendidikan Islam di Nusantara, tidaklah hanya sekedar kedudukan formalitasnya yang demikian kokoh hendak dikedepankan, namun sejauh mana substansi nilai-nilai spiritualitas Islam dapat tereduksi melalui internalisasi penyelenggaraan kegiatan pendidikan Islam yang telah sekian lama berjalan. Mengingat dalam batasbatas tertentu, hasil penyelenggaraan pendidikan Islam masih belum memenuhi idealitas yang dielukan, karena pada kebanyakan produknya didapati padanya menyandang split personality (pribadi yang pincang), terlihat misalnya hanya menguasai keilmuan agama tanpa terimbangi dengan penguasaan ilmu pengetahuan umum atau bahkan sains yang

1 Staf Fakultas Ilmu Tarbiyah Dan Keguruan Universitas Islam Negeri Maulana Malik Ibrahim Malang Jl. Gajayana No. 50 Malang 65144 
dapat bermanfaat dalam merespon perubahan dunia yang kian cepat seolah tanpa kompromi dengan kondisi antropologis-sosiologis apalagi dengan nilai-nilai religiusitas.

Celakanya, penguasaan keilmuan agama itupun tidak begitu holistik dan mendalam, terbukti seandainya pesan-pesan agama Islam dapat dipahami dengan paripurna maka aspek pengetahuan dunia akan include dalam orientasi pencapaian keilmuan yang harus digarap dengan serius, karena Islam begitu terang mengajarkan pentingnya memahami ilmu pengetahuan sehingga dapat membantu tugas kekhalifahan manusia di bumi. Lebih parah lagi, ajaran Islam yang dikuasai itupun hanya mampu bertahan pada tingkatan kajian dan studi, buktinya nilai-nilai spiritualitas Islam yang semestinya dijunjung tinggi dalam bangunan sikap dan perilaku layaknya sebagai muslim beraqidah jauh berbeda dengan ketika nilai-nilai keislaman dikaji dan didiskusikan.

Paradoks tersebut mengindikasikan bahwa fungsi pendidikan Islam sebagai pembentuk kepribadian insan kamil telah mengalami degradasi nilai atau sikap di dalam praktiknya. Taksonomi pendidikan Islam sebagai bingkai dibentuknya manusia yang paripurna yakni membentuk sikap affective domain, mengembangkan pengetahuan cognitive domain, serta melatihkan keterampilan psychomotoric domain, nampaknya belum menjadi domain yang utuh dalam tataran outcomes pendidikan Islam.

Atas gejala ini, sebagai upaya responsif sekaligus langkah awal pembenahan patut ditinjau kembali sejauh mana pendidikan Islam dipahami dan diselenggarakan. Berangkat dari pemahaman yang kurang memiliki ketepatan dengan apa yang dimaksudkan ajaran Islam mengenai pendidikan, bukan tidak mungkin akan berbanding lurus dengan arah penyelenggaraan kegiatan pendidikan Islam yang termanifestasikan melalui orientasi pencapaian hasil produknya. Asumsinya, pemahaman yang kurang benar akan terinternalisasikan dengan kurang benar pula yang pada gilirannya mendapatkan hasil tidak optimal.

Dengan maksud tidak membangun suasana pesimis, kiranya demikianlah yang terjadi dalam dunia pendidikan Islam kita, karenanya menjadi keharusan untuk memahami kembali dengan segera bagaimana pendidikan Islam dipahami dan diselenggarakan. Menggali kembali akar ajaran yang menjadi inspirasi dipahaminya tatanan pendidikan 
sesuai dengan tuntunan Islam yang kemudian dikemas kembali dalam bangunan struktur pendidikan Islam yang komprehensif dan benar tentunya memerlukan kerja yang tidak ringan. Walaupun demikian setidaknya inilah upaya yang coba akan dilakukan dalam narasi yang hendak disajikan berikut ini meskipun masih sangat sederhana.

\section{B. Merangkai Konsepsi Pendidikan Islam; Mengurai Kegagalan Praktik dan Orientasi}

Harus dimaklumi sampai saat ini belum ada formula pendidikan Islam yang kokoh dirumuskan secara praktis dan pragmatis serta dengan keahlian cukup tinggi dan akomodatif terhadap berbagai perubahan sehingga representatif dijadikan pedoman aplikatif dalam penyelenggaraannya. Setidaknya hal tersebut karena seperti Arifin mewanti-wantikan dalam merumuskan teori, konsep atau pengetahuan tentang pendidikan Islam harus melalui serangkaian tahapan yang mesti dilalui. Sebagai langkah awal adalah dengan meletakkan sumber pokok ajaran Islam (Qur'an dan Hadits) yang kemudian dipadu dengan pengalaman praktik pendidikan yang dilakukan umat Islam selama rentang sejarahnya, baik dari hasil pemikiran manusia yang bersifat mengembangkan makna sumber pokok ajaran Islam maupun temuan dari fakta pengalaman empirik dunia pendidikan. (Arifin, 1991: 1)

Benar pesimisme dan kekhawatiran di atas dapat dimengerti betapa banyak aspek yang harus diakomodasi dalam membangun formulasi pendidikan Islam, namun bagaimanapun juga hal ini harus tetap diupayakan, mengingat betapapun Islam telah mengajarkan pendidikan yang ideal ketika umatnya walaupun dengan teguh memegang keimanan agama Muhammad tidak mampu menterjemahkan ajaran tersebut dalam rumusan konsep pendidikan Islam yang tepat, maka tentunya pelaksanaan pendidikan Islam akan diselenggarakan dengan asal jalan.

Lebih jauh pendidikan merupakan bagian vital dalam kehidupan manusia. Pendidikan (terutama Islam) -dengan berbagai coraknyaberorientasi memberikan bekal kepada manusia (peserta didik) untuk mencapai kebahagiaan dunia dan akhirat. Oleh karena itu, semestinya pendidikan (Islam) selalu diperbaharui konsep dan aktualisasinya dalam 
rangka merespon perkembangan zaman yang selalu dinamis dan temporal, agar peserta didik dalam pendidikan Islam tidak hanya berorientasi pada kebahagiaan hidup setelah mati (eskatologis); tetapi kebahagiaan hidup di dunia juga bisa diraih.

Dalam kenyataannya, di kalangan dunia Islam telah muncul berbagai isu mengenai krisis pendidikan dan problem lain yang amat mendesak untuk dipecahkan (Syed Sajjad Husein \& Syed Ali Ashraf, 1986). Lebih dari itu, Isma'il Raji Al-Faruqi (1988: vii) mensinyalir bahwa didapati krisis yang terburuk dalam hal pendidikan di kalangan dunia Islam. Inilah yang menuntut agar selalu dilakukan pembaharuan (modernisasi) dalam hal pendidikan dan segala hal yang terkait dengan kehidupan umat Islam

Menggali informasi sejauh mana pendidikan Islam dirumuskan dan diperbaharui melalui berbagai konsep yang lahir dari para ahli yang concern dibidangnya, secara garis besar dapat disimpulkan bahwa Islam tetap menjadi kecenderungan perspektif, hanya saja dalam wilayah praksis ditemui banyak perbedaan. Marimba seorang pakar filsafat pendidikan misalnya telah mengelaborasi pengetahuannya terhadap pendidikan Islam dengan memberikan pengertian bahwa pendidikan Islam adalah bimbingan jasmani dan rohani berdasarkan hukum-hukum agama Islam menuju kepada terbentuknya kepribadian utama menurut ukuran-ukuran Islam. (Marimba, 1980: 131)

Dalam definisi ini tergambar bahwa Marimba membatasi pendidikan pada apa yang dilakukan pendidik. Akibatnya, hal-hal yang diperoleh peserta didik dari pengalamannya sendiri atau diperoleh dari interaksinya dengan alam lingkungan tidak dapat dikategorikan ke dalam lingkup pendidikan. Begitu pula dengan usaha yang dilakukannya sendiri untuk mengembangkan potensi dirinya. Jadi dengan kata lain, pendidikan menjadi amat terbatas pada sesuatu yang formal. Padahal tujuan akhir pendidikan dalam Islam, sebagai proses pembentukan diri peserta didik (manusia) agar sesuai dengan fitrah keberadaannya. (al-Nauquib al-Attas, 1984) Hal ini meniscayakan adanya kebebasan gerak bagi setiap elemen dalam dunia pendidikan -terutama peserta didik- untuk mengembangkan diri dan potensi yang dimilikinya secara maksimal.

Disamping itu dalam bentuk aplikatifnya tidak ada petunjuk pasti bagaimana proses pembimbingan yang dimaksudkan Marimba tersebut harus 
dijalankan dalam kegiatan pendidikannya. Ketika bangunan pemahaman tersebut dijadikan pijakan maka pengelola pendidikan Islam akan bebas berinovasi tanpa arah dan pencapaian kongkrit yang hendak dituju karena tidak adanya pedoman, jika demikian maka berdasarkan pengalaman historis dan teori pendidikan yang berkembang dapat disimpulkan arah pencapaian hasil kegiatan pendidikan Islam tidak akan memiliki kejelasan muara.

Masih tidak jauh berbeda, Ibrahimi seorang warga Negara Bangladesh merumuskan pendidikan Islam dengan :

Islamic education in true sense of the lern, is a system of education which enable a man to lead his life according to the Islamic ideology, so that he may easily mould his life in accordance with tenets of Islam". (Arifin, 1991: 3-4)

Ideal memang gambaran dan orientasi yang dikehendaki dalam formulasi pendidikan Islam Ibrahimi tersebut, namun secara teknis dalam definisi yang dikemukakanya kurang menyentuh aspek pelaksanaan pendidikan Islam yang seharusnya dijalankan. Definisi Ibrahimi hanya menyarankan agar sistem pendidikan Islam yang hendak dijalankan berpedoman pada ideologi dan hukum Islam. Padahal sekedar menegok kembali bahwa dalam konteks ideologi dan hukum dalam Islam sangatlah luas wilayah cakupannya, sementara dalam pendidikan Islam perlu penafsiran tersendiri. Setidaknya ganjalan ini akan menjadi kesulitan tersendiri dalam pelaksanaan penyelenggaraan pendidikan Islam.

Sementara itu Al-Attas menganggap formulasi wajah pendidikan Islam sebagai suatu sistem pendidikan terpadu. Dalam konteks tersebut paradigma keterpaduan pendidikan yang dikehendaki Al-Attas yakni dengan mengintegrasikan beragam ilmu dalam sistem pendidikan Islam, dimana Islam harus dihadirkan dan diajarkan dalam proses pendidikannya tidak hanya ilmu-ilmu agama saja, tetapi juga ilmu-ilmu rasional, intelek dan filosofis. Formulasi pendidikan Islam perspektif Al-Attas bertujuan mewujudkan manusia yang baik, yaitu manusia universal (al-Insân alKamîl), yang bercirikan : pertama, manusia yang seimbang, memiliki keterpaduan dua dimensi kepribadian berupa dimensi isoteric vertical yang intinya tunduk dan patuh kepada Allah dan dimensi eksoteric, dialectical, horizontal, membawa misi keselamatan bagi lingkungan sosial alamnya. 
Kedua; manusia seimbang dalam kualitas pikir, dzikir dan amalnya. (Achmadi, 1992: 130)

Karena itu Al-Attas berkeyakinan untuk menghasilkan manusia seimbang yang menyandang ciri tersebut merupakan suatu keniscayaan adanya upaya maksimal dalam mengkondisikan lebih dulu paradigma pendidikan Islam yang terpadu.

Secara makro orientasi pendidikan Al-Attas mengarah pada pendidikan yang bercorak moral religius dengan tetap menjaga prinsip keseimbangan dan keterpaduan sistem, yakni aspek moral-transendental (afektif) pada saat yang sama tidak mengabaikan aspek kognitif (sensual-logis) dan psikomotorik (sensual-empiris). Hal ini sinergi dengan aspirasi pendidikan Islami, yakni aspirasi yang bernafaskan moral dan agama, seperti Muhaimin jelaskan dalam taksonomi pendidikan Islami, dikenal adanya aspek transendental berupa domain iman, disamping domain kognitif, afektif dan psikomotorik. (Muhaimain, 1991: 72-73).

Paradigma pendidikan Islam terpadu yang digagas Al-Attas sampai saat ini telah berkembang pada tingkatan wacana yang mengagumkan walaupun bagi sebagian pihak saja. Meskipun demikian, sudah semestinya kita tidak terperangkap dalam gegap gempita kekaguman tersebut, mengingat peran pendidikan Islam sebagaimana Fasli Jalal kehendaki bukan hanya dipahami dalam konteks mikro [kepentingan anak didik yang dilayani melalui proses interaksi pendidikan], melainkan juga dalam konteks makro, yaitu kepentingan masyarakat yang dalam hal ini termasuk masyarakat bangsa, negara dan bahkan juga kemanusiaan pada umumnya sehingga pendidikan Islam integratif antara proses belajar di sekolah dengan belajar di masyarakat (learning society). (Fasli Jalal, 2001: 16-17)

Benar Al-Attas menghendaki keterpaduan sistem pendidikan Islam yang memungkinkan dilahirkanya produk pendidikan yang baik "insan kamil", akan tetapi secara eksplisit definisi rumusan pendidikan Islam perspektif al-Attas belum mengakomodasi kepentingan aplikatif konsep yang hendak dijalankan.

Merangkai berbagai pemahaman pendidikan Islam yang telah diformulasikan melalui sekian banyak definisi dengan segenap keragamannya diperoleh kesimpulan; formulasi definitif pendidikan Islam yang telah 
sekian lama berkembang belum mampu secara utuh menterjemahkan ruh ajaran Islam mengenai pendidikan. Terlihat pada masing-masing formula hanya mewakili sebagian aspek tertentu dan kurang menyentuh secara akomodatif aspek yang lain, akibatnya perkembangan kekinian kurang ter-up grad dengan baik sehingga dalam perjalanannya pendidikan Islam kurang mampu merespon dinamika modernitas peradaban.

\section{Hilangannya Ruh dan Bergesernya Landasan Ideologi; Fenomena Pendidikan Islam Kini}

Perkembangan pendidikan Islam baik pada tingkatan rumusan konsep, internalisasi dan perkembangan penyelenggaraan kegiatan pendidikannya, hingga kini harus diakui semakin jelas boleh dikatakan masih berada dalam posisi problematik antara determenisme historis dan realisme praktis. Di satu sisi pendidikan Islam belum sepenuhnya bisa keluar dari idealisasi kejayaan pemikiran dan peradaban Islam pada masa lampau yang hegemonik. Sementara di sisi lain, pendidikan Islam juga dipaksa berhadapan dengan tuntutan masa kini yang memiliki kecenderungan orientasi yang praktis-progresif, tegasnya pendidikan Islam menghadapi situasi kompetitif yang sangat tinggi, karena harus berhadapan dengan kekuatan pendidikan global

Dalam dataran historis-empiris, kenyataan tersebut acapkali menimbulkan dualisme dan polarisasi sistem pendidikan di tengah-tengah masyarakat muslim sehingga agenda tranformasi yang digulirkan menuju civil society misalnya melalui pendidikan Islam seakan berfungsi hanya sekedar tambal sulam saja. Oleh karena itu tak mengherankan apabila satu sisi masih saja didapati tampilan pendidikan Islam bercorak tradisional karena tetap memakai "baju lama” (the old fashion), sementara di sisi lain juga didapati pendidikan Islam yang bercorak materialistik-sekularisrik.

Benar, mengelola lembaga pendidikan hampir sama dengan mengelola lembaga nirlaba, karena lembaga pendidikan termasuk institusi pendidikan Islam merupakan nobel industry, yakni di satu sisi sebagai lembaga profit yang harus menguntungkan secara materi karena berkaitan dengan oprasional yang menyedot anggaran tinggi, disisi yang lain sebagai lembaga moral yang mengemban tanggung jawab kepada masyarakat yang harus 
mengawal dan memberikan jaminan kualitas hidup yang beradab bagi anak didik. Hanya saja yang menonjol adalah yang pertama dimana saat ini, banyak institusi pendidikan telah berubah menjadi industri bisnis, yang memiliki visi dan misi pragmatis.

Celakanya, orientasi pencapaian hasil pendidikannya mengalami hal serupa, sehingga kegiatan pendidikan juga diarahkan untuk melahirkan individu-individu pragmatis yang siap bekerja untuk meraih kesuksesan material dan profesi sosial yang diharapkan mampu memakmurkan diri dan komunitasnya (perusahaan dan Negara misalnya). Pendidikan dipandang secara ekonomis dan dianggap sebagai sebuah investment. "Ijazah" dianggap sebagai prioritas utama, ingin segera dan secepatnya diraih supaya modal yang selama ini dikeluarkan akan menuai keuntungan. Sistem pendidikan seperti ini sekalipun akan memproduksi anak didik yang memiliki status pendidikan tinggi, namun status tersebut tidak akan menjadikan mereka sebagai individu-individu yang kosmopolit. Karena itu, individu produk pendidikan semacam ini menjadi salah satu bentuk dari karakteristik split personality (pribadi yang pincang).

Disamping itu, Daoed Joesoef misalnya, mencatat permasalahan internal lain dalam dunia pendidikan meliputi permasalahan-permasalahan yang berhubungan dengan strategi pembelajaran, peran guru, dan kurikulum. (Daoed Joesoef, 2001: 210-225). Lebih penting lagi sesungguhnya problem kelembagaan nampaknya lebih patut disoroti, dimana kelembagaan pendidikan Islam saat ini ditemui dualisme atau bahkan dikotomi antar pendidikan umum dan pendidikan agama, yang agaknya merupakan warisan dari pemikiran Islam klasik yang memilah antara ilmu umum dan ilmu agama atau ilmu ghairu syariah dan ilmu syariah, seperti yang terlihat dalam konsepsi al-Ghazali. (Ali Issa Othman, 1981: 182).

Dualisme dikotomi sistem kelembagaan dalam pendidikan Islam yang berlaku selama ini merupakan permasalahan serius, bukan saja karena hal itu belum tuntas ditemukan formulasi yang tepat hingga sekarang, melainkan juga karena ia, menurut Ahmad Syafii Maarif hanya mampu melahirkan sosok manusia yang "pincang". Jenis pendidikan yang pertama akan melahirkan sosok manusia yang berpandangan sekuler, yang melihat agama hanya sebagai urusan pribadi. (Syafii Maarif, 1987: 3)

Sedangkan sistem pendidikan yang kedua melahirkan sosok manusia 
yang taat, tetapi miskin wawasan. Dengan kata lain, adanya dualisme dikotomi sistem kelembagaan pendidikan tersebut merupakan kendala untuk dapat melahirkan sosok manusia Indonesia "seutuhnya". Oleh karena itu Ahmad Syafii Maarif (1987: 3), menyarankan perlunya model pendidikan yang integrative.

Seperti disinggung sebelumnya, dalam penyelenggaraan kegiatan pendidikan, strategi pembelajaran juga menuai problem. Suyanto memaparkan, (Suyanto, 2007: 15-16)

era globalisasi dewasa ini mempunyai pengaruh yang sangat signifikan terhadap pola pembelajaran yang mampu memberdayakan para peserta didik. Tuntutan global telah mengubah paradigma pembelajaran dari paradigma pembelajaran tradisional ke paradigma pembelajaran baru. Suyanto menggambarkan paradigma pembelajaran yang berpusat pada guru, menggunakan media tunggal, berlangsung secara terisolasi, interaksi guru-murid berupa pemberian informasi dan pengajaran berbasis factual atau pengetahuan sebagai strategi pembelajaran tradisional. Berkaitan dengan hal tersebut Paulo Freire (2000: 51-52) menyebut strategi pembelajaran tradisional sebagai strategi pelajaran dalam "gaya bank" (banking concept).

Selanjutnya Suyanto menggambarkan strategi pembelajaran baru dengan ciri sebagai berikut: berpusat pada murid, menggunakan banyak media, berlangsung dalam bentuk kerja sama atau secara kolaboratif, interaksi guru-murid berupa pertukaran informasi dan menekankan pada pemikiran kritis serta pembuatan keputusan yang didukung dengan informasi yang kaya. Model pembelajaran baru ini disebut Paulo Freire (2000: 61) sebagai strategi pembelajaran "hadap masalah" (problem posing).

Meskipun dalam aspirasinya, sebagaimana dikemukakan di atas, dewasa ini terdapat tuntutan pergeseran paradigma pembelajaran dari model tradisional ke arah model baru, namun kenyataannya menunjukkan praktek pembelajaran lebih banyak menerapkan strategi pembelajaran tradisional dari pembelajaran baru. Hal ini agaknya dilatar belakangi keterbatasan guru dalam meng-up grud persinality-nya terhadap perkembangan strategi pembelajaran, kesimpulannya rendahnya professionalisme guru berbanding lurus dengan internalisasi strategi pembelajaran tradisional. 


\section{Menghadirkan Pendidikan Islam Paripurna; Redevinisi Konsep dan Restrukturisasi Internalisi}

Wacana pembaharuan pendidikan Islam bukanlah hal yang baru. Pada hampir setiap gejolak yang muncul kepermukaan terkait dengan formulasi pendidikan Islam dan tantangan yang harus dihadapinya urgensi pembaharuannya pun makin strategis.

Menapaki jejak sejarah masa lalu pada masa kejayaan Islam, pendidikan telah mampu menjalankan perannya sebagai wadah pemberdayaan peserta didik, namun seiring dengan kemunduran dunia Islam, dunia pendidikannya juga turut mengalami kemunduran. Bahkan dalam paradigma pun terjadi pergeseran dari paradigma aktif-progresif menjadi pasif-defensif. Akibatnya, pendidikan Islam mengalami proses 'isolasi diri' dan termarginalkan dari lingkungan di mana ia berada.

Mudjib dan Mudzakir memberikan deskripsi yang nampak mendekati kesempurnaan berangkat dari keseluruhan aspek yang melekat erat pada pendidikan Islam. Dalam kacamata keduanya, pendidikan Islam dirumuskan dengan proses transinternalisasi pengetahuan dan nilai Islam kepada peserta didik melalui upaya pengajaran, pembiasaan, bimbingan, pengasuhan, pengawasan dan pengembangan potensinya guna mencapai keselarasan dan kesempurnaan hidup di dunia dan di akhirat. (Abdul Mujib dan Yusuf Mudzakkir, 2006: 27-28) Rumusan ini berkonsekensi pada lima unsur pokok pendidikan Islam yaitu :

1. Proses transinternalisasi. Upaya dalam pendidikan Islam dilakukan secara bertahap, berjenjang, terencana, terstruktur, sistemik dan terusmenerus dengan transformasi dan internalisasi ilmu pengetahuan dan nilai Islam pada peserta didik.

Dalam padangan lain Muchlis Usman memahami proses transinternalisasi tersebut sebagai bentuk dari proses kegiatan pendidikan Islam tidak disarankan hanya sekedar transfer knowledge, karena jika pendidik hanya menyampaikan content materi seolah tidak bertanggung jawab terhadap bagaimana anak didik menerima, memahami atau bahkan menginternalisasikan materi pembelajaran, padahal secara historis diselenggarakannya kelembagaan pendidikan dimaksudkan untuk mencerdaskan anak didik agar memahami arti kehidupan di dunia 
dan bagaimana menjalaninya karena berbias pada kehidupan akhirat kemudian.

2. Pengetahuan dan nilai Islam. Materi yang diberikan kepada peserta didik adalah ilmu pengetahuan dan nilai Islam, yaitu pengetahuan dan nilai yang diturunkan dari Tuhan (Ilahiyah), atau materi yang memiliki criteria epistemologi dan aksiologi Islam, sehingga produk pendidikan memiliki wajah-wajah Islam dalam setiap perilaku dan aktifitas kehidupanya. Dalam hal ini disandarkan pada QS. Fushshilat ayat 53, yang di dalamnya terdapat tiga obyek, yaitu obyek afaqi, yang berkaitan dengan alam fisik (baik langit maupun bumi); obyek anfusi, yaitu berkaitan dengan alam psikis (kejiwaan atau bathiniah); dan obyek haqqî atau qur'anî, yang berkaitan dengan sistem nilai untuk mengarahkan kehidupan spiritual manusia.

3. Kepada peserta didik. Pendidikan diberikan kepada peserta didik sebagai subjek dan objek pendidikan. Dikatakan subjek karena ia menjadi sasaran dan transformasi ilmu pengetahuan dan nilai Islam, agar ilmu dan nilai itu tetap lestari dari generasi ke genarasi berikutnya.

4. Melalui upaya pengajaran, pembiasaan, bimbingan, pengasuhan, pengawasan dan pengembangan potensinya. Tugas pokok pendidikan adalah memberikan pengajaran, pembiasaan dan bimbingan, pengasuhan, pengawasan dan pengembangan pada peserta didik agar terbentuk dan berkembang daya kreativitas dan produktivitasnya tanpa mengabaikan potensi dasarnya.

5. Guna mencapai keselaransan dan kesempurnaan hidup di dunia dan akhirat. Tujuan akhir pendidikan Islam adalah tercipta insane kamil (manusia sempurna), yaitu manusia yang mampu menyelaraskan dan memenuhi kebutuhan dunia dan akhirat; dan kebutuhan fisik, psikis, social dan spiritual. Orientasi pendidikan Islam tidak hanya memenuhi hajat hidup jangka pendek, seperti pemenuhan kebutuhan duniawi, tetapi juga memenuhi hajat hidup jangka panjang seperti pemenuhan kebutuhan di akhirat kelak. (Abdul Mujib dan Yusuf Mudzakkir, 2006: 28-29) 


\section{E. Kesimpulan}

Setelah ditelusuri, secara general kegagalan formulasi pendidikan Islam selama ini disinyalir karena banyak dipengaruhi ideologi luar yang semestinya Islam dijadikan satu-satunya prioritas sumber pijakan. Sementara pengalaman empirik yang muncul kemudian hendaknya sebatas dijadikan pertimbangan setiap kali evaluasi dilakukan.

Sebagai makhluk beraqidah sudah semestinya epistimologi pendidikan Islam sebagai matrik konseptual aktivitas kultural-performatif yang berkaitan langsung dengan dinamika praksis sosial-budaya perlu progresif mempertegas jari diri keberpihakannya pada tindakan penyadaran dan pemberdayaan. Dengan basis ijtihad dan tajdid, epistimologi pendidikan Islam perlu memadukan secara sinergis-dialektis antara epistimologi bayani, irfani dan burhani dalam struktur hierarkis-piramidal yang bermata ayat kauniyah dan ayat qauliyah dalam kerangka humanisasi, liberasi, transendensi demi mewujudkan pendidikan Islam transformatif.

Pengembangan ilmu pendidikan Islam jelas membutuhkan landasan epistemologis yang kokoh dan jelas yang hanya bisa dihasilkan melalui pemahaman yang tuntas tentang warisan klasik mengenai pendidikan Islam dan kemudian dipadu dengan pengertian yang jelas tentang persoalan dan tantangan yang dihadapi pendidikan Islam masa kini dan masa mendatang. Dalam konteks inilah seorang ahli pendidikan Islam perlu mengetahui sebaik-baiknya warisan klasik Islam dibidangnya, dan kemudian memetakannya dan mencari relevansinya terhadap kondisi pendidikan Islam masa sekarang dan masa mendatang. Tanpa hal tersebut, bahkan klaim 'keislaman' dari ilmu pendidikan Islam perlu dipertanyakan.

\section{DAFTAR PUSTAKA}

Freire, Paulo, 2000. Pendidikan Kaum Tertindas, alih bahasa Oetomo Dananjaya dkk. Jakarta: LP3ES.

Joesoef, Daoed, 2001. "Pembaharuan Pendidikan dan Pikiran”, dalam Sularto (ed .). Masyarakat Warga dan Pergulatan Demokrasi: Antara Cita dan Fakta. Jakarta: Kompas. 
Maarif, Ahmad Syafii, 1987. "Masalah Pembaharuan Pendidikan Islam", dalam Ahmad Busyairi dan Azharudin Sahil (ed.). Tantangan Pendidikan Islam. Yogyakarta: LPM UII.

Maarif. Ahmad Syafii, 1996. "Pendidikan Islam dan Proses Pemberdayaan Umat”. Jurnal Pendidikan Islam, No. 2 Th.I/Oktober 1996.

Othman, Ali Issa, 1981. Manusia Menurut al-Ghazali, alih bahasa Johan Smit dkk. Bandung: Pustaka.

Suyanto, 2007, “Tantangan Profesionalisme Guru di Era Global”, Pidato Dies Natalis ke-43 Universitas Negeri Yogyakarta, 21 Mei. 
